\title{
İki Ekmeklik Buğday (Triticum aestivum L.) Çeşidinde Hümik/Fulvik Asit Uygulamasının Tane Verimi ve Bazı Kalite Özelliklerine Etkisi
}

\author{
Soner Arduç ${ }^{1}$ Zeki Mut ${ }^{2 *}$, Özge Doğanay Erbaş Köse ${ }^{3}$ \\ Geliş / Received: 21/02/2020 \\ Revize / Revised: 05/03/2020 \\ Kabul / Accepted: 05/03/2020 \\ $\ddot{O ̈ Z}$ \\ Bu çalışma, iki ekmeklik buğday çeşidinde farklı dozlardaki hümik/fulvik asit uygulamalarının verim ve bazı \\ kalite özelliklerine etkilerini belirlemek amacıyla 2013-2015 yılları yetiştiricilik dönemlerinde Yozgat ili \\ Sarıkaya ilçesinde yürütülmüştür. Deneme tesadüf bloklarında bölünmüş parseller deneme desenine göre üç \\ tekrarlamalı olarak gerçekleştirilmiştir. Araştırmada çeşitlerin bitki boyu, başak uzunluğu, metrekaredeki başak \\ sayısı, tane verimi, hektolitre ağırlığı, bin tane ağırlığı, protein içeriği, Zeleny sedimentasyon değeri, yaş gluten \\ içeriği, yağ oranı, nişasta içeriği, kül oranı, asit deterjanda çözünmeyen lif (ADF) ve nötr deterjanda çözünmeyen \\ lif (NDF) değerleri incelenmiştir. Bitki boyu, metrekaredeki başak sayısı, tane verimi ve bin tane ağırlığı üzerine \\ hümik/fulvik asit uygulamasının etkisi istatistiki olarak \% 1 seviyesinde önemli olmuştur. İki yılın ortalamasına \\ göre en yüksek tane verimi $392.2 \mathrm{~kg} \mathrm{da}^{-1}$ ile dekara $300 \mathrm{ml}$ hümik/fulvik asit uygulamasından elde edilmiştir.
}

Anahtar Kelimeler- Buğday, hümik-fulvik asit, tane verimi, kalite, çeşit

\footnotetext{
2*Sorumlu yazar iletişim: zeki.mut@ bilecik.edu.tr (https://orcid.org/0000-0002-1465-3630) Bilecik Seyh Edebali Üniversitesi, Ziraat ve Doğa Bilimleri Fakültesi, Tarla bitkileri Bölümü, Bilecik

'İletişim: sonerarduc@ @otmail.com (https://orcid.org/0000-0002-9624-1508)

Yozgat Sarlkaya Ziraat Odası, Yozgat

3 iletişim: ozgedoganay.erbas@bilecik.edu.tr (https://orcid.org/0000-0003-0429-3325)

Bilecik Şeyh Edebali Üniversitesi, Ziraat ve Doğa Bilimleri Fakültesi, Tarla bitkileri Bölümü, Bilecik
} 


\title{
The Effect Of Humic/Fulvic Acid Application on Grain Yield and Some Quality Traits in Two Bread Wheat (Triticum aestivum L.)
}

\begin{abstract}
This study was carried out with the aim of determining the effect of different amounts of humic/fulvic acid application on the yield and some quality traits of two bread wheat cultivars in Yozgat-Sarıaya ecological conditions between 2013 and 2015 growth seasons. Experiments were established using split block design with three replications. In this study, spike length, spike number per square meters, grain yield, test weight, 1000 kernel weight, protein content, Zeleny sedimentation value, wet gluten content, fat ratio, starch content, ash ratio, ADF and NDF value were investigated. The effect of humic/fulvic acid application on plant height, spike number per square meters, grain yield and thousand kernel weights were statistically significant at $1 \%$ level. According to the average of two years, the highest grain yield was obtained with $392.2 \mathrm{~kg} \mathrm{da}^{-1}$ by applying 300 $\mathrm{ml}$ of humic/fulvic acid per decares.
\end{abstract}




\section{GİRIS}

Sürekli artan dünya nüfusu ve azalan tarım alanlarına karşın son yıllarda yeni üretim teknikleri ile birlikte geliştirilen yeni çeşitlerin kullanımı yaygınlaşmaya başlamıştır. Günümüzde artan dünya nüfusunu yeterli ve dengeli besleyebilmek için birim alandan alınan ürün miktarının arttırılması ve tarım arazilerinin verimliliklerinin ve miktarının korunması önem arz etmektedir.

Türkiye tarım topraklarının \% 85'i bazik reaksiyonludur. Bu toprakların da \% 94'ü organik madde miktarı bakımından fakirdir. Ayrıca toprakların \% 58'inin kireçli olmasından dolayı yapısal bozuklukları, bitki besin elementlerinin yetersizliği, yetersiz su depolanması, fiksasyon ve denge bozukluğu sonucunda bitkilerin yetersiz beslenmesi meydana gelmekte ve bu durum bitkisel üretimde verim ve kalite düşüklüğüne neden olmaktadır [1].

Tarımsal alanda verimin arttırılması ve kaliteli ürün elde edilmesi amacıyla uzun yıllardır bir çok çalışma yapılmış ve halende yapılmaktadır. Verim ve kaliteyi artırmak için kimyasal gübre kullanımı uzun yıllardan beri kullanılan en etkili yöntemlerden biridir. Bitkiler bazı inorganik besin maddelerini gübreleme ile karşılamaktadır. Bu kimyasal gübrelerin tamamı bitki tarafından kullanılamamakta ve kullanılmayan kısım toprak derinlerine sızarak yer altı kaynak sularına, denizlere, göllere karışarak önemli ekolojik sorunlara yol açmaktadır. Ekolojik dengeyi korumak için tarımda organik madde kullanımı her geçen gün önem kazanmaktadır. Önemli toprak organik maddelerinden olan hümik asit ve fulvik asitin toprakların kimyasal, fiziksel ve biyolojik yapıları üzerine olumlu etkileri bulunmaktadır. Bu etkilerden en önemlileri ise çimlenmeyi teşvik etmesi, bitkinin toprak altı ve toprak üstü aksamını geliştirmesi ve çiçeklenmeyi arttırmasıdır. Buna ilaveten bitkinin toprakta bulunan su ve havadan daha iyi yararlanmasını ve dengeli beslenmesini sağlayarak bitki verimi ve kalitesini arttırmada yararlı olabilmektedir [1]. Ayrıca hümik ve fulvik asitler, kimyasal gübrelerin etkinliğini arttırdığından aşırı gübre kullanımını azaltarak, ekonomiye katkı sağlanmanın yanı sıra çevrenin korunmasına da yardımcı olur.

Ülkemizde buğday ekim alanları bakımından son sınırına gelmiş, hatta yetiştiriciliğine uygun olmayan alanlarda bile buğday üretimi gerçekleştirilmektedir. Bu nedenle birim alandan alınan verimin artırılması çalışmaları önem kazanmıştır [2]. Buğday yetiştiriciliğinde verim yanında kalitenin de göz önünde bulundurulması gerekmektedir. Dünya'da ve ülkemizde özellikle buğday üretiminde herhangi bir nedenle azalma olduğunda un ve un mamüllerinden elde edilen gıda ürünlerinin fiyatları yükselerek bütün insanlı̆g etkilemektedir. Bu nedenle ülkeler için yeterli düzeyde buğday üretiminin sağlanması ve stoklarında yeterince buğday ürünü bulundurması stratejik bir önem arz etmektedir [3]. Türkiye'de buğday üreticilerinin gelirlerinin diğer bitkisel ürünleri üreten üreticilere göre düşük olmasının ana sebebi, buğday tarımının büyük ölçüde kurak koşullarda yapılmasından dolayı verimin düşük olmasıdır. Ayrıca bazı bölgelerimizde buğdayın alternatifi olmadığından zorunlu olarak buğday-nadas ekim yöntemi yapılmaktadır. Polikültür tarımın yapıldığı yörelerimizde bile işçiliğinin ucuz olması nedeniyle çiftçi buğdayı tercih etmektedir [4].

Dünyada ekim alanı 214.7 milyon ha, üretimi 735.2 milyon ton olan buğdayın, ülkemizde ekim alanı 6.8 milyon ha üretimi 19.0 milyon tondur. Dünya'da ve ülkemizde tahıllar içerisinde ekiliş ve üretimi bakımından buğday ilk sırada yer almaktadır [5, 6]. Yozgat ilinde toplam ekim alanının \% 74'ünü buğday oluşturmaktadır [5]. Yozgat buğday yetiştiriciliği açısından çok uygun ekolojik koşullara sahiptir. Ancak, bölgede daha kaliteli ürün ve yüksek verim alabilmek için uygun yetiştirme tekniklerinin ve yüksek verimli çeşitlerin kullanılması gerekmektedir. Bu çalışma Yozgat koşullarında iki farklı ekmeklik buğday çeşidine uygulanan hümik-fulvik asidin verim ve kalite üzerine etkisini belirlemek amacıyla yürütülmüştür. 
e-ISSN: 2458-7575 (http://dergipark.gov.tr/bseufbd)

\section{MATERYAL VE YÖNTEM}

Deneme alanlarının toprak özellikleri incelendiğinde her iki yılın toprakları; tınlı bünyeye sahip, hafif alkali, tuzsuz, yüksek miktarda kireç içeren, organik madde bakımından düşük, fosfor bakımından orta, potasyum bakımından yeterli durumdadır (Tablo 1).

Tablo 1. 2013-15 Araştırma Yeri Toprağının Bazı Fiziksel ve Kimyasal Özellikleri*

\begin{tabular}{lcc}
\hline Özellik & $2013-2014$ & $2014-2015$ \\
\hline Bünye $(\%)$ & 47.3 & 40.7 \\
pH & 7.36 & 7.61 \\
Tuz $(\%)$ & 0.019 & 0.012 \\
$\mathrm{Kirec}\left(\mathrm{CaCO}_{3}\right)(\%)$ & 41.3 & 46.71 \\
$\left.\mathrm{Organik} \mathrm{Madde}^{2} \%\right)$ & 1.94 & 1.20 \\
$\mathrm{P}_{2} \mathrm{O}_{5}(\mathrm{~kg} / \mathrm{da})$ & 6.93 & 5.60 \\
$\mathrm{~K}_{2} \mathrm{O}(\mathrm{kg} / \mathrm{da})$ & 48.18 & 57.2 \\
\hline *Analizler Sarkaya Ziraat Odası laboratuvarında yapılmıștır. & &
\end{tabular}

Tablo 2' de görüldüğü gibi, kuru tarım alanlarında verim için çok önemli bir faktör olan yağış denemenin 2013-2014 yetiştirme sezonunda, 2014-2015 yetiştirme sezonuna ve uzun yıllar ortalamasına göre daha yüksek olmuştur. Denemenin birinci yılında $617.2 \mathrm{~mm}$, ikinci yılında $580.2 \mathrm{~mm}$ ve uzun yıllar ortalamasında da $552.0 \mathrm{~mm}$ yağış gerçekleşmiştir. 2013-2014 yetiştirme sezonunda 2014-2015 yetiştirme sezonu ve uzun yıllar ortalama sıcaklığına kıyasla daha yüksek olmuştur.

Tablo 2. Deneme yerine ait 2013-2015 yılları arası ve uzun yıllar ortalaması iklim verileri

\begin{tabular}{|c|c|c|c|c|c|c|c|c|c|c|c|}
\hline & Ekim & Kasım & Aralık & Ocak & Şubat & Mart & Nisan & Mayıs & Haziran & Temmuz & Ort/Top. \\
\hline \multicolumn{12}{|c|}{ Toplam Yağıș (mm) } \\
\hline 2013-2014 & 72.6 & 61.4 & 53.3 & 58.7 & 17.6 & 116.7 & 31.6 & 121.8 & 79.8 & 3.7 & 617.2 \\
\hline 2014-2015 & 40.6 & 21.6 & 16.5 & 54.5 & 69.6 & 115.2 & 28.0 & 131.8 & 95.3 & 7.1 & 580.2 \\
\hline Uzun Yıllar & 36.8 & 56.1 & 76.2 & 68.7 & 62.8 & 67.0 & 62.3 & 65.3 & 44.4 & 12.4 & 552.0 \\
\hline \multicolumn{12}{|c|}{ Ortalama Sıcaklık $\left({ }^{\circ} \mathrm{C}\right)$} \\
\hline 2013-2014 & 10.8 & 4.6 & 4.2 & 1.4 & 3.3 & 5.6 & 11 & 13.3 & 16.6 & 21.5 & 9.23 \\
\hline 2014-2015 & 11.8 & 6.1 & -1.6 & -1.2 & 0.8 & 4.7 & 6.1 & 13.5 & 16.0 & 19.6 & 7.58 \\
\hline Uzun Yillar & 10.3 & 4.6 & 0.5 & -1.8 & -0.8 & 3.0 & 8.5 & 13.1 & 16.8 & 19.7 & 7.39 \\
\hline \multicolumn{12}{|c|}{ Ortalama Nem (\%) } \\
\hline 2013-2014 & 70.0 & 65.0 & 77.0 & 65.0 & 68.0 & 70.0 & 64.5 & 58.7 & 70.0 & 58.0 & 66.6 \\
\hline 2014-2015 & 72.1 & 63.4 & 81.3 & 70.4 & 76.6 & 69.6 & 62.1 & 61.8 & 73.5 & 57.4 & 68.8 \\
\hline Uzun Yıllar & 59.3 & 68.2 & 72.0 & 64.0 & 71.0 & 70.0 & 61.0 & 65.0 & 62.1 & 58.4 & 65.1 \\
\hline
\end{tabular}

Çalışmada, bitkisel materyal olarak Renan ve Krasunia Odeska ekmeklik buğday çeşitleri, hümik/fulvik asit kaynağı olarak \% 30 hümik + fulvik asit içeren bitkisel menşeli ürün kullanılmıştır. Bu ürünün toplam organik madde içeriği \% 40, toplam azot içeriği \% 2.6, suda çözünen potasyum oksit içeriği $\left(\mathrm{K}_{2} \mathrm{O}\right) \% 3.5$ ve pH's1 4-6 arasındadir.

Araştırma Yozgat'ın Sarıkaya ilçesine bağlı Domarca köyündeki çiftçi arazisinde 2013-2014 ve 20142015 yetiştirme sezonunda iki yıl yürütülmüştür. Bölünmüş parseller deneme desenine göre kurulan denemede ana parsellere hümik/fulvik asit dozları, alt parseller çeşitler yerleştirilmiştir. Parsel boyu $6 \mathrm{~m}$ ve eni $1.2 \mathrm{~m}$ olan $7.2 \mathrm{~m}^{2}$ büyüklüğündeki parsellere sıra arası $15 \mathrm{~cm}$ olacak şekilde 8 sıra ve 3 tekrarlamalı olarak ekim yapılmıştır. Parseller arasındaki olası bulaşmaları önlemek için $1.5 \mathrm{~m}$, bloklar arasında ise $2 \mathrm{~m}$ boşluk bırakılmıştır. Ekim işlemi her iki yılda da 8 Ekim tarihinde $\mathrm{m}^{2}$,ye 600 tohum olacak şekilde ve deneme mibzeriyle yapılmıştır. Ekimle beraber dekara saf madde üzerinden $7 \mathrm{~kg} \mathrm{P}_{2} \mathrm{O}_{5}$ ve $2.7 \mathrm{~kg}$ saf N ve kardeşlenme döneminde $5 \mathrm{~kg}$ azot gübresi uygulanmıştır. Gübreler ekimle birlikte diamonyum fosfat kompoze gübre (DAP) ve kardeşlenme 
döneminde üre gübresi verilerek uygulanmıştır. Çalışmada dekara 0 (Kontrol), 100 ml, $200 \mathrm{ml}, 300 \mathrm{ml}$ ve $400 \mathrm{ml}$ olacak şekilde 5 farklı hümik/fulvik asit dozu ele alınmıştır. Hümik/fulvik asit dozları her iki yılda da çıkıştan sonra bitkilerin 4-5 yapraklı olduğu devrede tekseferde yapraklara uygulanmıştır. Yabancı otlara karşı kimyasal mücedele yapılmıştır.

Araştırmada bitki boyu, başak uzunluğu, $\mathrm{m}^{2}$ ' de başak sayısı, tane verimi, bin tane ağırlı̆̆ı, hektolitre ağırlığı, protein oranı, Zeleny sedimentasyon ve yaş gluten değerleri, yağ ve kül oranı, protein ve nişasta içeriği, asit deterjanda çözünmeyen lif (ADF) ve nötr deterjanda çözünmeyen lif (NDF) özellikleri araştırılmıştır. Çalışmada ölçüm ve analizler Mut ve ark. (2017)'na göre yapılmıştır [7]. Çalışmada elde edilen verilerin varyans analizleri MSTATC paket programı kullanılarak analiz edilmiştir. Yapılan analiz sonucunda farklılık gösteren özelliklerin ortalamaları arasında gruplandırma Duncan çoklu karşılaştırma testi ile değerlendirilmiştir.

\section{BULGULAR VE TARTIŞMA}

Çalışmada, bitki boyu bakımından yıl, hümik/fulvik asit, çeşit, yıl $\times$ hümik/fulvik asit, yıl $\times$ çeşit ve çeşit x hümik/fulvik asit interaksiyonları istatistiki olarak \% 1 seviyesinde önemli bulunmuştur (Tablo 3).

Tablo 3. Çalışmada ele alınan özellikler için yıllar üzerinden birleştirilmiş varyans analiz sonuçları

\begin{tabular}{|c|c|c|c|c|c|c|c|c|}
\hline Varyasyon Kaynakları & SD & BB & BU & $\mathbf{M}^{2}$ 'BS & TV & BTA & HA & PO \\
\hline Yil (Y) & 1 & $2884.26 * *$ & $15.30 * *$ & $66068.0^{* * *}$ & $41717.0 * *$ & 3.95 & $22.2 * *$ & $21.6^{* *}$ \\
\hline Tekerrür & 4 & 3.08 & 0.06 & 2478.7 & 1042.8 & 4.20 & 2.05 & 1.19 \\
\hline Hümik/Fulvik Asit (HFA) & 4 & $113.21^{* *}$ & $1.66^{* *}$ & $11519.2^{* *}$ & $34132.0 * *$ & $17.00 * *$ & 0.959 & $0.39 *$ \\
\hline $\mathrm{Y} \times \mathrm{HFA}$ & 4 & $27.89^{* *}$ & $0.56^{* *}$ & $5219.2 *$ & $5128.9 * *$ & $31.21 * *$ & 0.455 & 0.13 \\
\hline $\mathrm{Hata}_{1}$ & 16 & 2.88 & 0.06 & 1269.0 & 819.8 & 1.50 & 0.467 & 0.12 \\
\hline Çeșit (Ç) & 1 & $448.27 * *$ & 0.58 & 220.4 & $16364.7 * *$ & 4.16 & $81.9 * *$ & 0.32 \\
\hline $\mathrm{Y} \times \mathrm{C}$ & 1 & $112.07 * *$ & 0.01 & 7.35 & 4101.0 & 13.44 & $62.22 * *$ & 0.04 \\
\hline $\mathrm{C} \times \mathrm{HFA}$ & 4 & $40.31 * *$ & $0.61 * *$ & 570.5 & 2818.6 & 7.90 & $1.1 * *$ & 0.29 \\
\hline $\mathrm{Y} \times \mathrm{HFA} \times \mathrm{C}$ & 4 & 7.53 & $0.94 * *$ & 854.7 & 408.8 & $30.84 * *$ & $2.27 * *$ & 0.23 \\
\hline $\mathrm{Hata}_{2}$ & 20 & 3.22 & 0.15 & 337.0 & 1220.0 & 3.81 & 0.138 & 0.14 \\
\hline $\mathrm{VK} \%$ & & 2.38 & 4.70 & 5.55 & 10.23 & 4.66 & 0.48 & 3.21 \\
\hline Varyasyon Kaynakları & SD & SD & YGO & YO & NO & KO & ADF & NDF \\
\hline Y1l (Y) & 1 & $1218.6^{* *}$ & $109.0 * *$ & $0.57 * *$ & $162.3 * *$ & $0.04 *$ & $13.4^{* *}$ & $42.6 * *$ \\
\hline Tekerrür & 4 & 50.16 & 5.98 & 0.36 & 0.54 & 0.03 & 2.16 & 4.37 \\
\hline Hümik/Fulvik Asit (HFA) & 4 & 22.30 & $2.32 *$ & 0.02 & 0.89 & 0.01 & 0.03 & 0.93 \\
\hline $\mathrm{Y} \times \mathrm{HFA}$ & 4 & 2.33 & 0.78 & 0.01 & 1.00 & 0.01 & 0.09 & 0.34 \\
\hline $\mathrm{Hata}_{1}$ & 16 & 7.73 & 0.59 & 0.04 & 0.34 & 0.01 & 0.47 & 0.81 \\
\hline Çeşit (Ç) & 1 & $47.88^{* *}$ & 1.20 & $1.17 * *$ & 6.87 & $0.01 * *$ & 0.17 & 0.10 \\
\hline $\mathrm{Y} \times \mathrm{C}$ & 1 & $25.30 *$ & 0.66 & $0.90 * *$ & $9.84 * *$ & $0.12 * *$ & 0.19 & 0.01 \\
\hline $\mathrm{C} \times \mathrm{HFA}$ & 4 & 4.00 & 1.44 & 0.01 & $4.25 * *$ & 0.00 & 0.07 & 0.26 \\
\hline $\mathrm{Y} \times \mathrm{HFA} \times \mathrm{C}$ & 4 & 1.91 & 1.37 & $0.03 * *$ & $1.99 *$ & 0.01 & 0.05 & 0.26 \\
\hline $\mathrm{Hata}_{2}$ & 20 & 4.19 & 0.66 & 0.01 & 0.60 & 0.01 & 0.09 & 0.26 \\
\hline VK \% & & 9.68 & 3.66 & 5.14 & 1.20 & 3.59 & 6.76 & 3.29 \\
\hline
\end{tabular}

Birinci yıl $68.6 \mathrm{~cm}$ olan bitki boyu ikinci yıl $82.5 \mathrm{~cm}$ ölçülmüştür. Farklı dozlardaki hümik/fulvik asit uygulamalarında ortalama bitki boyları 70.4 (kontrol) ile $77.8(300 \mathrm{ml}) \mathrm{cm}$ arasında değişmiş ve en uzun bitki boyu $77.8 \mathrm{~cm}$ ile $300 \mathrm{ml}$ hümik/fulvik asit uygulamasından elde edilmiştir. Ayrıca 200, 300 ve $400 \mathrm{ml}$ uygulamalarında bitki boyu istatistiki olarak aynı grupta yer almıştır. Farklı miktarlardaki hümik/fulvik asit dozları uygulanan buğday çeşitlerinin bitki boylarına bakıldığında Krasunia Odeska çeşidi $78.2 \mathrm{~cm}$ ile Renan $(72.8 \mathrm{~cm}$ ) çeşidinden daha uzun bitki boyuna sahipolmuştur (Tablo 3). Çeşit x hümik/fulvik asit interaksiyonu değerlendirildiğinde ise en kısa ve uzun bitki boyu Krasunia Odeska çeşidinde sırasıyla kontrol (70.3 cm) ve 300 ml uygulamasında $(82.5 \mathrm{~cm})$ ölçülmüştür. Ankara koşullarında yapılan bir çalışmada hümik/fulvik asit uygulamasının bazı çeşitlerde bitki boyunda azalma gösterirken çinko ile beraber uygulanması sonucu bitki boyunda artışlar göstermiş, bitki boyları 101-112.9 cm arasında bulunmuştur [8]. Bitki boyu çevre koşullaından etkilenen önemli bir çeşit özelliğidir [9]. Yağış miktarının düştükçe ve ortalama sıcaklık yükseldikçe bitki 
boyuda azalmaktadır [10]. Buğdayda bitki boyu çeşide, iklim ve toprak faktörleri ile yetiştirme tekniğine bağlı olarak değişmektedir $[2,11]$. Dünyanın farklı yerlerinde daha önceki yıllarda yapılan çalışmalarda hümik/fulvik asit uygulamasının buğday da bitki boyunu artırdığı bildirilmiştir $[12,13,14]$.

Başak uzunluğu üzerine y1l, hümik/fulvik asit, y1l $\times$ humik/fulvik asit, çeşit $\mathrm{x}$ hümik/fulvik asit ve y1l $\times$ humik asit $\times$ çeşit interaksiyonları istatistiki olarak $(\mathrm{P}<0.001)$ önemli bulunmuştur (Tablo 3). Hümik/fulvik asit uygulamalarında en uzun başak uzunluğuortalamas $8.54 \mathrm{~cm}$ ile $200 \mathrm{ml}$ dozunda elde edilmiştir. Bunu $300 \mathrm{ml}$ $(8.43 \mathrm{~cm})$ ve $100 \mathrm{ml}(8.32 \mathrm{~cm})$ hümit asit uygulamaları izlemiş ve bu dozlarda elde edilen başak uzunluğu istatistiki olarak $200 \mathrm{ml}$ uygulama dozu ile aynı grupta olmuştur. En kısa başak uzunluğu $7.59 \mathrm{~cm}$ ile kontrol uygulamasında elde edilmiştir. Çalışmanın ikinci yılı başak uzunluğu ortalaması $8.70 \mathrm{~cm}$ olmuş ve birinci yıl ölçülen başak uzunluğuna $(7.70 \mathrm{~cm})$ göre daha uzun olmuştur (Tablo 4). Başak uzunluğu ortalaması Krasunia Odeska çeşidinde $(8.31 \mathrm{~cm})$ Renan çeşidinden $(8.11 \mathrm{~cm})$ daha uzun olmuş ancak istatistiki olarak farklılık görülmemiştir. Çeşit x hümik/fulvik asit interaksiyonu değerlendirildiğinde ise en kısa ve uzun başak uzunluğu Krasunia Odeska çeşidinde sırasıyla kontrol $(7.53 \mathrm{~cm})$ ve $400 \mathrm{ml}$ uygulamasında $(8.63 \mathrm{~cm})$ ölçülmüştür. Başak uzunluğu kullanılan çeşide ve çevre şartlarına göre önemli değişiklik gösterir ve tane verimi üzerine önemli etkiye sahiptir [11].Daha önce yapılan çalışmalarda da belli düzeyde humik asit uygulamalarınında buğdayda başak uzunluğunu arttı̆ğ belirlenmiş̧tir $[14,15,16]$.

Metrekaredeki başak sayısı bakımından yıl ile hümik/fulvik asit dozları arasında çok önemli ve yıl x hümik/fulvik asit interaksiyonu istatistiki olarak önemli bulunmuştur (Tablo 3). Metrekaredeki başak sayısı hümik/fulvik asit uygulamaları ile birlikte artış göstermiş kontrol, 100, 200, 300 ve $400 \mathrm{ml}$ uygulamalarında sırasiyla $287.0,312.8,340.7,346.3$ ve 366.3 adet olmuş ve istatistiki olarak önemli fark tespit edilmiştir. Daha önceki yıllarda yapılan çalışmalarda hümik/fulvik asit uygulamasının buğday da $\mathrm{m}^{2}$ 'deki başak sayısını artırdığı bildirilmiştir [15, 17]. 2013-2014 yetiştirme döneminde 363.8 adet olan $\mathrm{m}^{2}$ 'deki başak sayıs1, 2014-2015 yetiştirme döneminde 297.4 adet olmuştur. İstatistiki olarak fark olmamakla birlikte $\mathrm{m}^{2}$ 'deki başak sayısı Renan çeşidinde (332.5 adet) Krasunia Odeska (328.7 adet) çeşidinden daha yüksek bulunmuştur (Tablo 4). Denemenin birinci yılında $\mathrm{m}^{2}$ deki başak sayısının ikinci yılından daha yüksek olmasının nedenin birinci yıl düşen yağış miktarın daha yüksek olması ve toprak yapısındaki farklılıktan kaynaklandığı düşünülmektedir.

Tablo 4. Bitki boyu, başak uzunluğu, $\mathrm{m}^{2}$ 'de başak sayısı ve tane verimi için yıllar üzerinden birleştirilmiş ortalamalar ve oluşan gruplar*

\begin{tabular}{|c|c|c|c|c|c|}
\hline & & BB (cm) & BU (cm) & $\mathrm{m}^{2} \mathrm{BS}$ (adet) & TV (kg/da) \\
\hline \multirow{2}{*}{ Çeşit } & Renan & $72.8 \mathrm{~b}$ & 8.11 & 332.5 & $325.1 \mathrm{~b}$ \\
\hline & K. Odeska & $78.2 \mathrm{a}$ & 8.31 & 328.7 & $358.1 \mathrm{a}$ \\
\hline \multirow{5}{*}{$\begin{array}{l}\text { Hümik/fulvik asit } \\
\left(\mathrm{ml} \mathrm{da}^{-1}\right)\end{array}$} & 0 & $70.4 \mathrm{c}$ & $7.59 \mathrm{c}$ & $287.0 \mathrm{c}$ & $259.4 \mathrm{c}$ \\
\hline & 100 & $74.8 \mathrm{~b}$ & $8.32 \mathrm{ab}$ & $312.8 \mathrm{bc}$ & $324.7 \mathrm{~b}$ \\
\hline & 200 & $76.9 \mathrm{a}$ & $8.54 \mathrm{a}$ & $340.7 \mathrm{ab}$ & $348.4 \mathrm{~b}$ \\
\hline & 300 & $77.8 \mathrm{a}$ & $8.43 \mathrm{ab}$ & $346.3 \mathrm{ab}$ & $392.2 \mathrm{a}$ \\
\hline & 400 & $77.5 \mathrm{a}$ & $8.19 \mathrm{~b}$ & $366.3 \mathrm{a}$ & $383.2 \mathrm{a}$ \\
\hline \multirow{2}{*}{ Yil } & 2013-14 & $68.6 \mathrm{~b}$ & $7.70 \mathrm{~b}$ & $363.8 \mathrm{a}$ & $368.0 \mathrm{a}$ \\
\hline & 2014-15 & $82.5 \mathrm{a}$ & $8.70 \mathrm{a}$ & $297.4 \mathrm{~b}$ & $315.2 \mathrm{~b}$ \\
\hline
\end{tabular}

* Her sütunda aynı harfle gösterilen ortalamalar arasında 0.01 önem düzeyine göre fark yoktur. BB: Bitki boyu, BU: Başak uzunluğu, M²' BS: Metrekaredeki başak sayısı, TV: Tane verimi

Araştırmada, tane verimi bakımından yıl, hümik/fulvik asit, çeşit ve yıl $\times$ hümik/fulvik asit interaksiyonu \% 1 seviyesinde önemli bulunmuştur (Tablo 3).Tane verimi ortalaması birinci ve ikinci yıl sırasıyla 368.0 ve $315.2 \mathrm{~kg} \mathrm{da}^{-1}$ olmuştur. Hümik/fulvik asit uygulamalarında en yüksek tane verimi ortalaması sirasiyla $300 \mathrm{ml}\left(392.2 \mathrm{~kg} \mathrm{da}^{-1}\right), 400 \mathrm{ml}\left(383.2 \mathrm{~kg} \mathrm{da}^{-1}\right), 200 \mathrm{ml}\left(348.4 \mathrm{~kg} \mathrm{da}^{-1}\right), 100 \mathrm{ml}\left(324.7 \mathrm{~kg} \mathrm{da}^{-1}\right) \mathrm{ve}$ kontrol $\left(259.4 \mathrm{~kg} \mathrm{da}^{-1}\right)$ uygulamalarından elde edilmiştir. Ayrıca en yüksek tane verimine sahip $300 \mathrm{ml}$ ile 400 $\mathrm{ml}$ uygulamaları arasında tane verimi bakımından istatistiki olarak fark olmamıştır. Yıl ve hümik/fulvik asit uygulamalarının ortalamasına göre Krasunia Odeska çeşidi $358.1 \mathrm{~kg} \mathrm{da}^{-1}$ tane verimi ile Renan (325.1 kg da $\left.{ }^{-1}\right)$ 
çeşidinden daha yüksek değere sahip olmuştur (Tablo 4). Daha önceki yıllarda yapılan çalışmalar buğday da tane veriminin çeşide, bölgenin ekolojik yapısına ve uygulanan kültürel işlemlere göre değiştiğini göstermektedir [1823]. Yapılan çalışmada buğday verimi gübresiz parsellerde $304.5 \mathrm{~kg} / \mathrm{da}$, dekara 1 lt hümik asit uygulanan parsellerde $406.15 \mathrm{~kg} / \mathrm{da}$, dekara 2 lt hümik asit uygulanan parsellerde $378.2 \mathrm{kd} / \mathrm{da}$ olarak belirlenmiştir [39]. Güngör ve Dumlupınar (2019) 18 ekmeklik buğday çeşidinin Bolu ekolojik koşullarında verim, verim unsurları ve kalite özelliklerinin belirlenmesi amacıyla 2016-2017 ve 2017-2018 vejetasyon dönemlerinde yaptıkları çalışmada tane verimininin dekara 515.2-790.7 kg arasında değiştiğini bildirmişlerdir [40]. Yapılan diğer çalışmada da 2014-2016 yılında Bursa Uludağ Üniversitesi Ziraat Fakültesi Tarımsal Uygulama ve Araştırma Merkezi deneme tarlalarında 13 buğday genotipi denenmiş ve dekara ortalama $335.8 \mathrm{~kg}$ verim elde edilmiştir [41].

Bin tane ağırlığı bakımından hümik/fulvik asit, yıl $\times$ humik asit ve yıl $\times$ humik asit $\times$ çeşit interaksiyonu istatistikî olarak \% 1 seviyesinde önemli bulunmuştur (Tablo 3). Hümik/fulvik asit uygulamalarında en yüksek bin tane ağırlığı ortalaması $43.6 \mathrm{~g}$ ile $100 \mathrm{ml}$ dozunda elde edilmiştir. Diğer dozlarda bin tane ağırlığı 40.6 ile $42.1 \mathrm{~g}$ arasında değişmiş ve istatistiki olarak aynı grupta yer almıştır. Her iki çeşidin bin tane ağırlı̆̆ının 300 ve $400 \mathrm{ml}$ hümik/fulvik asit uygulamalarında azaldığı belirlenmiştir. Renan ve Krasunia Odeska çeşitlerinin bin tane ağırlığı sırasıyla 42.2 ile 41.6 g olmuş ve aralarındaki fark istatistiki olarak önemsiz bulunmuştur (Tablo 5). Çeşit ve hümik/fulvik asit uygulamalarının ortalaması olarak çalışmanın birinci ve ikinci yılında sırasıyla bin tane ağırlığı 41.6 ve 42.1 g olmuş ve aralarındaki fark istatistiki olarak önemsiz bulunmuştur. Bin tane ağırlığ hem kalite ile hemde verimle bağlantılı bir özelliktir. Genetik yapı ve çevresel faktörler bin tane ağırlığına etki eden iki önemli faktördür. Ekmeklik buğday genotipleri üzerine farklı araştırıcılar tarafından yapılan çalışmalarda bin tane ağırlıklarının değiştiği bildirmişlerdir [19, 24, 25].

Birleştirilmiş yıllara ait varyans analiz sonucunda, hektolitre ağırlı̆̆ı üzerine yıl ve çeşit ile yıl $\times$ çeşit, hümik/fulvik asit $\times$ çeşit ve yıl $\times$ hümik/fulvik asit $\times$ çeşit interaksiyonlarının çok önemli etkide bulunduğu tespit edilmiştir (Tablo 3). Çeşit ve hümik/fulvik asit dozlarının ortalamasına göre hektolitre ağırlığı ortalaması 20132014 yetiştirme döneminde $77.1 \mathrm{~kg}, 2014-2015$ yetiştirme döneminde $78.3 \mathrm{~kg}$ olmuştur. İki yılın ortalamasına göre ise Renan çeşidi $76.5 \mathrm{~kg}$, Krasunia Odeska çeşidi ise $78.9 \mathrm{~kg}$ hektolitre ağırlığınasahip olmuş ve bu fark istatistiki olarak \% 1 seviyesinde önemli bulunmuştur. İki yılın birleştirilmiş sonuçlarına göre hümik/fulvik asit uygulamalarında ortalama hektolitre ağırlığı değerinin 77.3 ile $78.0 \mathrm{~kg}$ arasında değiştiği ve hümik/fulvik asit uygulamasının hektolitre ağırlığı üzerine etkili olmadığı görülmüştür (Tablo5). Un verimini belirleyen önemli kalite kriterlerinden olan hektolitre ağırlığı buğdayda önemli bir özelliktir. Buğdayda hektolitre ağırlığının birçok özelliğe bağlı olarak değişmektedir. Bunlar çeşit, çevre şartları, yatma, kültürel uygulamalar, hastalık ve zararlılar gibi faktörlerdir [2, 18, 26].

Protein oranı üzerine yıllar arasındaki farkın istatistiki olarak \% 1, hümik/fulvik asit uygulamaları arasındaki farkın ise \% 5 seviyesinde önemli olduğu tespit edilmiştir. Protein oranı üzerine diğer faktör ve interaksiyonların ise istatistiki olarak etkisinin önemli olmadığı belirlenmiştir (Tablo 3).Tablo5'de görüldüğü gibi çalışmanın birinci ve ikinci yılında tane protein oranı sırasıyla \% 12.4 ve \% 11.2 olmuştur. Birleştirilmiş yılların sonucuna göre hümik/fulvik asit uygulamalarında tane protein oranı en yüksek kontrol (\% 11.9$)$ ve dekara $200 \mathrm{ml}$ (\% 11.9) uygulamalarında elde edilirken en düşük dekara $300 \mathrm{ml}$ (\% 11.5) uygulamasında elde edilmiştir. Çeşitlerinin tane protein oranları arasındaki fark istatistiki olarak önemli olmamış, Renan ve Krasunia Odeska çeşitlerinin protein oranları sırasıyla \% 11.9 ve \% 11.7 bulunmuştur. Ekmek yapımında kullanılacak buğdayların protein oranının \% 11'in üzerinde olması gerekir. Tane protein oranı ekmeğin pişme ve besleme özelliklerini önemli derecede etkilemektedir. Bundan dolayı üzerinde en çok çalışılan kalite kriterlerinden biridir. Yapılan çalışmalarda buğdayda protein oranını kullanılan çeşidin, yetiştirilen bölgenin ve uygulanan kültürel işlemlerin etkilediği bildirilmiştir [19, 21, 22, 27, 28, 29]. 
Yozgat koşullarında yürütülen bu çalışmada birleştirilmiş yıllara göre iki ekmeklik buğday çeşidinin Zeleny sedimantasyon değerine ait varyans analiz sonuçları Tablo 3'de verilmiştir. Zeleny sedimantasyon değeri bakımından yıllar ve çeşitler arasında \% 1 seviyesinde, yıl $\times$ çeşit interaksiyonun ise $\% 5$ seviyesinde önemli olduğu belirlenmiştir. Sedimantasyon değeri birinci yıl $25.6 \mathrm{ml}$, ikinci yıl $16.6 \mathrm{ml}$ bulunmuştur. İki yılın ortalamasına göre ortalamaZeleny sedimantasyon değeri Renan çeşidinde $(22.0 \mathrm{ml})$ Krasunia Odeska çeşidinden $(20.2 \mathrm{ml})$ daha yüksek olmuş ve istatistiki olarak çeşitler arasındaki fark önemli bulunmuştur.Birleştirilmiş yılların sonucuna göre hümik/fulvik asit uygulamalarında Zeleny sedimantasyon değeri en yüksek kontrol (23.4 $\mathrm{ml})$ işleminden elde edilirken en düşük dekara $300 \mathrm{ml}(19.9 \mathrm{ml})$ uygulamasında elde edilmiştir. Genel olarak hümik/fulvik asit uygulama dozu arttıkça Zeleny sedimantasyon değeri azalış göstermiştir (Tablo 5). Sedimentasyon değeri arttıkça ekmek hacmi de artacağından, ekmeklik buğdayda sedimentasyon değerinin yüksek olması istenir [21]. Sedimentasyon değeri sonuçlarının değerlendirilmesinde; $\leq>33$ (çok iyi), 28-33 (iyi), 22-27 (orta), 16-21 (kötü), 15 (çok kötü) parametreler kullanılmaktadır [7]. Sedimentasyon değerinin çeşitlere göre farklılık gösterdiği farklı araştırıcılar tarafindan bildirmişlerdir [18, 19, 22, 23, 25, 30, 31, 32, 35].

Yaş gluten oranı bakımından yıllar arasında \% 1,hümik/fulvik asit dozları arasında \% 5 seviyesinde önemli fark bulunmuştur (Tablo 3). Çeşit ve hümik/fulvik asit dozlarının ortalamasına göre yaş gluten birinci yıl $\% 23.6$, ikinci y1l \% 20.9 bulunmuştur. Kontrol, 100, 200, 300 ve $400 \mathrm{ml} \mathrm{da}^{-1}$ hümik/fulvik asit uygulamalarında yaş gluten değerleri sırasıyla \% 22.6, 22.3, 22.7, 21.6 ve 22.2 olmuş ve istatistiki olarak en düşük yaş gluten oranı dekara $300 \mathrm{ml}$ uygulamasında elde edilmiştir. Renan ve Krasunia Odeska çeşitlerinin yaş gluten değerleri Sirasıyla \% 22.4 ve 22.1 olmuştur (Tablo 5). Bir çok araştırıcı tarafindan yapılan çalışmalarda yaş gluten değerinin çeşitlere göre farklılık gösterdiği bildirilmiştir [7, 30, 31, 33, 34].

Tablo 5. Bin tane ağırlığı, hektolitre ağırlığı, protein oranı, sedimentasyon değeri ve yaş gluten oranı için yıllar üzerinden birleştirilmiş ortalamalar ve oluşan gruplar

\begin{tabular}{|c|c|c|c|c|c|c|}
\hline \multirow{3}{*}{ Çeşit } & & BTA (g) & HA (kg) & PO (\%) & SD (\%) & YGO (\%) \\
\hline & Renan & 42.2 & $76.5 \mathrm{~b}$ & 11.9 & $22.0 \mathrm{a}$ & 22.4 \\
\hline & K.Odeska & 41.6 & $78.9 \mathrm{a}$ & 11.7 & $20.2 \mathrm{~b}$ & 22.1 \\
\hline \multirow{5}{*}{$\begin{array}{l}\text { Hümik/fulvik asit } \\
\left(\mathrm{ml} \mathrm{da}^{-1}\right)\end{array}$} & 0 & $42.1 \mathrm{~b}$ & 77.3 & $11.9 \mathrm{a}$ & 23.4 & $22.6 \mathrm{a}$ \\
\hline & 100 & $43.6 \mathrm{a}$ & 77.7 & $11.8 \mathrm{ab}$ & 20.7 & $22.3 \mathrm{a}$ \\
\hline & 200 & $42.1 \mathrm{~b}$ & 78.0 & $11.9 \mathrm{a}$ & 20.5 & $22.7 \mathrm{a}$ \\
\hline & 300 & $41.0 \mathrm{~b}$ & 77.9 & $11.5 b$ & 19.9 & $21.6 \mathrm{~b}$ \\
\hline & 400 & $40.6 \mathrm{~b}$ & 77.6 & $11.8 \mathrm{ab}$ & 21.1 & $22.2 \mathrm{ab}$ \\
\hline \multirow{2}{*}{ Y1l } & 2013-14 & 41.6 & $77.1 \mathrm{~b}$ & $12.4 \mathrm{a}$ & $25.6 \mathrm{a}$ & $23.6 \mathrm{a}$ \\
\hline & 2014-15 & 42.1 & $78.3 \mathrm{a}$ & $11.2 \mathrm{~b}$ & $16.6 \mathrm{~b}$ & $20.9 \mathrm{~b}$ \\
\hline
\end{tabular}

* Her sütunda aynı harfle gösterilen ortalamalar arasında 0.01 önem düzeyine göre fark yoktur. BTA: Bin tane ağırlı̆̆ ağırlığı, PO: Protein oranı, SD: Sedimentasyon değeri, YGO: Yaş gluten oranı

Yozgat koşullarında yürütülen bu çalışmada birleştirilmiş yıllara göre iki ekmeklik buğday çeşidinin yağ oranına ait varyans analiz sonuçları Tablo 3 'de verilmiştir.Yağ oranı bakımından yıllar arasındaki fark \%1 seviyesinde önemli bulunmuş, ayrıca yıl $\times$ çeşit ve yıl $\times$ doz $\times$ çeşit interaksiyonlarının çok önemli olduğu tespit edilmiştir.Yağ oranı birinci yıl \% 1.27, ikinci y1l \% 1.46 bulunmuştur. İki yılın ortalamasına göre ortalama yağ oranıKrasunia Odeska çeşidinde (\% 1.43) Renan çeşidinden (\% 1.23) daha yüksek olmuş ve istatistiki olarak çeşitler arasındaki fark önemli bulunmuştur. Birleştirilmiş yılların sonucuna göre hümik/fulvik asit uygulamalarında yağ oranı bakımından istatistiki olarak fark olmamakla birlikte en yüksek \% 1.42 ile dekara 100 $\mathrm{ml}$ uygulamasindan edilirken bunu dekara $200 \mathrm{ml}$ (\% 1.42), $300 \mathrm{ml}$ (\% 1.34), kontrol (\% 1.32) ve $400 \mathrm{ml}$ (\% 1.17)uygulamaları takip etmiştir (Tablo 6).

Birleştirilmiş yıllara ait varyans analiz sonucunda, nişasta oranı yıllara göre $\% 1$ seviyesinde farklı bulunmuştur. Ayrıca yıl $\times$ çeşit ve hümik/fulvik asit $\times$ çeşit interaksiyonlarının çok önemli etkide bulunduğu tespit edilmiştir (Tablo 3). Nişasta oranı birinci y1l \% 62.8, ikinci y1l \% 66.1 bulunmuş ve istatistiki olarak yıllar 
arasındaki fark önemli olmuştur. Kontrol, 100, 200, 300 ve $400 \mathrm{ml} \mathrm{da}^{-1}$ hümik/fulvik asit uygulamalarında nişasta oranları sırasıyla \% 64.5, 64.4, 64.2, 64.9 ve 64.2 olmuş ve istatistiki olarak uygulamalar arasında fark olmamıştır. Renan ve Krasunia Odeska çeşitlerinin nişasta oranları sırasıyla \% 64.1 ve 64.8 bulunmuştur (Tablo 6). Yapılan çalışmalarda nişasta oranının çeşitlere ve çevre şartlarına bağlı olarak değiştiği belrlenmiştir [26, 33, $35,36,37]$.

Birleştirilmiş yıllara ait varyans analiz sonucunda, kül oranı üzerine yıllar arasında \% 5, çeşitler arasında \% 1 seviyesinde fark olmuştur. Kül oranı üzerine yıl $\times$ çeşit interaksiyonu da \% 1 seviyesinde önemli bulunmuştur (Tablo 3). Kül oranı denemenin ikinci yılında (\% 1.64) birinci yılından (\% 1.59) daha yüksek bulunmuştur. Yılların birleştirilmiş sonucuna göre kül oranınahümik/fulvik asit uygulamalarının etkisinin istatistiki olarak önemli olmadı̆̆ıtespit edilmiştir. Tane kül oranları kontrol, 100, 200, 300 ve $400 \mathrm{ml} \mathrm{da}^{-1}$ hümik/fulvik asit uygulamalarında sırasıyla \% 1.61, 1.62, 1.61, 1.63 ve 1.61 olarak tespit edilmiştir. Çalışmada Renan çeşidinin kül oranı \% 1.66 olmuş ve Krasunia Odeska çeşidinden (\% 1.57) daha yüksek kül oranına sahip olduğu görülmüştür (Tablo 6).Kül oranı buğdayın çeşidi, yetiştirildiği iklim ve toprak özelliklerine göre farklılık gösterdiği bildirilmiştir [7, 29, 30, 31, 33, 35].

Tablo 6. Yağ oranı, nişasta oranı, kül oranı, ADF ve NDF için yıllar üzerinden birleştirilmiş ortalamalar ve oluşan gruplar

\begin{tabular}{|c|c|c|c|c|c|c|}
\hline & & YO (\%) & NO(\%) & $\operatorname{KO}(\%)$ & $\operatorname{ADF}(\%)$ & $\operatorname{NDF}(\%)$ \\
\hline \multirow{2}{*}{ Çeşit } & Renan & $1.23 \mathrm{~b}$ & 64.1 & 1.66 & 4.32 & 15.5 \\
\hline & K. Odeska & $1.43 \mathrm{a}$ & 64.8 & 1.57 & 4.43 & 15.5 \\
\hline \multirow{5}{*}{$\begin{array}{l}\text { Hümik/fulvik asit } \\
\left(\mathrm{ml} \mathrm{da}^{-1}\right)\end{array}$} & 0 & 1.32 & 64.5 & 1.61 & 4.32 & 15.9 \\
\hline & 100 & 1.42 & 64.4 & 1.62 & 4.41 & 15.6 \\
\hline & 200 & 1.40 & 64.2 & 1.61 & 4.43 & 15.4 \\
\hline & 300 & 1.34 & 64.9 & 1.63 & 4.32 & 15.1 \\
\hline & 400 & 1.17 & 64.2 & 1.61 & 4.42 & 15.5 \\
\hline \multirow{2}{*}{$Y_{11}$} & 2013-14 & $1.27 \mathrm{~b}$ & 62.8 & 1.59 & 3.9 & 16.3 \\
\hline & 2014-15 & $1.46 \mathrm{a}$ & 66.1 & 1.64 & 4.84 & 14.7 \\
\hline
\end{tabular}

oranı, ADF: Asit deterjanda çözünmeyen lif, NDF: Nötr deterjanda çözünmeyen lif

Yılların birleştirilmiş sonuçlarına göre ADF ve NDF değerleri bakımından yıllar arasındaki fark \% 1 seviyesinde önemli bulunmuştur. Çeşitler ve hümik/fulvik asit uygulamaları arasındaki fark ise istatistiki olarak önemsiz olmuştur (Tablo 3). ADF değeri birinci yıl \% 3.90, ikinci yıl \% 4.84 bulunmuştur. NDF değeri ise birinci yıl \% 16.34, ikinci yıl \% 14.65 olmuştur. ADF ve NDF değerleri Renan çeşidinde sırasıyla \% 4.32 ve \% 15.5, Krasunia Odeska çeşidinde \% 4.43 ve \% 15.5 bulunmuştur. Kontrol, 100, 200, 300 ve $400 \mathrm{ml} \mathrm{da}$ ${ }^{1}$ hümik/fulvik asit uygulamalarında ADF değerleri sırasıyla \% 4.32, 4.41, 4.43, 4.32 ve 4.42ve NDF değerleri ise \% 15.9, 15.6, 15.4, 15.1 ve 15.5 olarak tespit edilmiştir (Tablo 6). Eekmeklik buğday çeşitlerinde yapılan çalışmalarda ADF ve NDF değerlerinin çeşitlere gore değiştiği bildirmişlerdir [7, 26, 27, 28, 38].

\section{SONUÇ}

Uygulanan hümik/fulvik asidin farklı dozlarının iki ekmeklik buğday çeşidinde verim ve kaliteye etkisinin araştırıldığı bu çalışmada bitki boyu, $\mathrm{m}^{2}$ 'deki başak sayısı, tane verimi ve bin tane ağırlığıhümik/fulvik asit uygulamalarına göre istatistiki olarak \% 1 seviyesinde önemli farklılık göstermiştir. İki yılın ortalamasına göre en yüksek tane verimi $392.2 \mathrm{~kg} \mathrm{da}^{-1}$ ile dekara $300 \mathrm{ml}$ hümik/fulvik asit uygulamasından elde edilmiştir. Çeşitler arasında bitki boyu, tane verimi, hektolitre ağırlığı, sedimantasyon değeri, yağ oranı ve kül oranı bakımından \% 1 seviyesinde fark bulunmuş olup, bitki boyu, tane verimi, hektolitre ağırlı̆̆1 ve yağ oranı bakımından Krasunia Odeska çeşidi, sedimantasyon ve kül oranı bakımından Renan çeşidi daha yüksek 
değerlere sahip olmuştur. Tüm değerlendirmelere gore kalite özelliklerine hümik/fulvik asit uygulamasının etkisinin önemli olmadı̆̆ı belirlenmiştir.

\section{TEŞEKKÜR}

$\mathrm{Bu}$ makale Soner ARDUÇ’un Yüksek Lisans tezinin bir bölümüdür. 2016 y1lında Yozgat Bozok Üniversitesi Fen Bilimleri Enstitüsü tarafından kabul edilmiştir.

\section{KAYNAKLAR}

[1] Gezgin, S., Dursun, N. \& Yılmaz, F.G. (2012). Bitki yetiştiriciliğinde humik ve fulvik asit kaynağı olan TKİhumas'ın kullanımı. SAÜ Fen Edebiyat Dergisi, 1: 159-163.

[2] Mut, Z., Aydın, N., Özcan, H. \& Bayramoğlu H.O. (2005). Orta Karadeniz Bölgesinde ekmeklik buğday genotiplerinin verim ve bazı kalite özelliklerinin belirlenmesi, GOÜ. Ziraat Fakültesi Dergisi, 22 (2): 85 93.

[3] Süzer, S. (2007). Buğday tarımı ve önemi, Hasad Bitkisel Üretim Dergisi, 23 (270): 64-68.

[4] Kızılaslan, H. (2004). Dünya'da ve Türkiye'de buğday üretimi ve uygulanan politikaların karşılaştırılması. GOÜ. Ziraat Fakültesi Dergisi, 21 (2): 23-38.

[5] Türkiye İstatistik Kurumu. (2018). Türkiye İstatistik Kurumu. http://www.tuik.gov.tr/PreTabloArama.do (erişim tarihi: 20.02.2020).

[6] Food Agriculture Organization. (2019). Statistical Databases, http://faostat.fao.org, (erişim tarihi: 20.02.2020).

[7] Mut, Z., Erbaş Köse, Ö. D. \& Akay, H. (2017). Bazı ekmeklik buğday (Triticum aestivum L.) çeşitlerinin tane verimi ve kalite özelliklerinin belirlenmesi. Anadolu Tarım Bilimleri Dergisi, 32(1): 85-95.

[8] Kaya, M., Atak, M., Çiftçi, C. Y., \& Ünver, S. (2005). Çinko ve Humik Asit uygulamalarının ekmeklik buğday (Triticum aestivum L.)'da verim ve bazı verim öğeleri üzerine etkileri. Süleyman Demirel Üniversitesi Fen Bilimleri Enstitüsü Dergisi, 9(3).

[9] Dağüstü, N. \& Bölük, M. (2001).Yedi ekmeklik buğday diallel melezlerinin kimi tarımsal özellikleri. Uludağ Üniversitesi Ziraat Fakültesi Dergisi, (16): 211-223.

[10] Mut, Z., Ayan, I. \& Mut, H. (2006) Evaluation of forage yield and quality at two phenological stages of triticale genotypes and other cereals grown under rainfed conditions, Bangladesh J. Bot., 35(1): 45-53.

[11] Korkut, O. \& Bilgin, K. Z. (2005). Bazı ekmeklik buğday (Triticum aestivum L.) çeşit ve hatlarının tane verimi ve bazı fenolojik özelliklerinin belirlenmesi. Tekirdağ Ziraat Fakültesi Dergisi, 2 (1): 58-65.

[12] Khan, R.U., Rashid, A., Khan, M.S.\& Ozturk, E. (2010). Impact of humic acid and chemical fertilizer application on growth and grain yield of rainfed wheat (Tilticum Aestivum L.). Pakistan J. Agric. Res. 23: $3-4$.

[13] Arjumend, T., Abbasi, M.K.\& Rafique, E. (2015) Effects of lignite-derived humic acid on some selected soil properties, growth and nutrient uptake of wheat (Triticum aestivum L.) grown under greenhouse conditions. Pak. J. Bot., 47(6):2231-2238. 
[14] Manal, F. M., Thalooth, A.T. Amal, G. A. Magda, H. M. \& Elewa, T. A. (2016). Evaluation of the effect of chemical fertilizer and humic acid on yield and yield components of wheat plants (Triticum aestivum L.) grown under newly reclaimed sandy soil. International Journal of ChemTech Research, 9 (8):154-61.

[15] Radwan, F. I., Gomaa, M. A., Rehab, I. F. \& Samera, I. A. (2015). Impact of humicacid application, foliar micronutrients and biofertilization ongrowth, productivity and quality ofwheat (Triticum aestivum, L.). Middle East Journal of Agriculture, 4 (2): 130-140.

[16] Attia, M.A. \& Abd El Salam, A.A. (2016). Effect of mineral, organic and bio-fertilizer on yield and yield components of bread wheat at Siwa Oasis. Alex. J. Agric. Sci. vol. 61(3): 211-219.

[17] Antoun, L.W., Sahar, M.Z. \& Hanaa, H.R. (2010). Influence of compost, N-mineral and humic acid on yield and chemical composition of wheat plants. J. Soil Sci. and Agric. Engi. Mansoura Univ., 1(11): 1131-1143.

[18] Aydın, N., Bayramoğlu, H.O., Mut, Z. \& Özcan, H. (2005). Ekmeklik buğday (Triticum aestivum L.) çeşit ve hatlarının Karadeniz koşullarında verim ve kalite özelliklerinin belirlenmesi. AÜZF Tarım Bilimleri Dergisi, 11(3): 257-262.

[19] Mut, Z., Aydın, N., Bayramoğlu, N.O. \& Özcan, H. (2007). Bazı ekmelik buğday (Triticum aestivum L.) genotiplerinin verim ve başlıca kalite özelliklerinin belirlenmesi. OMÜ Ziraat Fakültesi Dergisi, 22(2): 193-201.

[20] Mut, Z., Aydin, N., Bayramoğlu, H.O. \& Özcan. H. (2010). Stability of some quality traits in bread wheat (Triticum aestivum L.) genotypes. J. Environ. Biol., 31: 489-495.

[21] Yazar, S., Salantur, A., Özdemir, B., Alyamaç, M. E., Evlice, A. K., Pehlivan, A., Akan K. \& Aydoğan, S. (2013). Orta Anadolu Bölgesi ekmeklik buğday 1slah çalışmalarında bazı tarımsal karakterlerin araştırılması. Tarla Bitkileri Merkez Araştırma Enstitüsü Dergisi, 22(1): 32-40.

[22] Aktaş, B. \& Eren, H. (2014). Bazı ekmeklik buğday (Triticum aestivum L.) çeşitlerinin tane verimi stabilitesi ve kalite özelliklerinin belirlenmesi. Tarla Bitkileri Merkez Araştırma Enstitüsü Dergisi, 23(2): 69-76.

[23] Özen, S. \& Akman, Z. (2015). Yozgat ekolojik koşullarında bazı ekmeklik buğday çeşitlerinin verim ve kalite özelliklerinin belirlenmesi. Süleyman Demirel Üniversitesi Ziraat Fakültesi Dergisi 10 (1): 35-43.

[24] Kendal, E. \& Doğan, Y. (2013). Diyarbakır koşullarında bazı ekmeklik buğday (Triticum aestivum L.) genotiplerinin tane verimi ve bazı kalite özelliklerinin belirlenmesi. YYÜ Tar. Bil. Derg., 23(3): 199-208.

[25] Naneli, İ., Sakin, M.A., Kıral, A.S. (2015). Tokat-Kazova şartlarında bazı ekmeklik buğday (Triticum aestivum L.) çeşitlerinin veri \& ve kalite özelliklerinin belirlenmesi. GOÜ. Ziraat Fak. Der. 32(1): $91-103$.

[26] Campbell, L. D., Boila, R. J., Stothers, S. C. (1995). Variation in the chemical composition and test weight of barley and wheat grain grown at selected locations throughout Manitoba. Can. J. Anim. Sci., 75 (2): 239246.

[27] Barteczko, J., Augustyn, R. , Lasek, O. \& Smulikowska, S. (2009). Chemical composition and nutritional value of different wheat cultivars for broiler chickens. Journal of Animal and Feed Sciences, 18: 124-131.

[28] Žilic, S., Dodig, D., Milašinovic Šeremešic, M., Kandic, V., Kostadinovic, M., Prodanovic S.\& Saviç, D. (2012). Small grain cereals compared for dietary fibre and protein contents. GENETIKA, 43(2): 381-395.

[29] Anjum, M.I., Ghazanfar, S.\& Begum, I. (2014). Nutritional composition of wheat grains and straw influenced by differences in varieties grown under uniform agronomic practices. Inter. J. Vet. Sci, 3(3): 100-104. 
[30] Ereifej, K. I., Al-Karaki, G. N. \& Hammouri, M. K. (2007). Variability of some physico-chemical characteristics of wheat cultivars grown under arid and semiarid mediterranean conditions. International Journal of Food Properties, 4(1): 91-101.

[31] Egesel, C.Ö., Kahrıman, F., Tayyar, Ş.\& Baytekin, H. (2009). Ekmeklik buğdayda un kalite özellikleri ile dane veriminin karşılıklı etkileşimleri ve uygun çeşit seçimi. Anadolu J. Agric. Sci. 24: 76-83.

[32] Akçura, M., 2011. The relationships of some traits in Turkish winter bread wheat landraces. Turk J. Agric. For., 35: 115-125.

[33] Mahla, R., Madan, S., Munjal, R. \& Hasija, R. J. (2015). Drought stress induced changes in quality and yield parameters and their association in wheat genotypes. Environment and Ecology, 33(4): 1639-1643.

[34] Liniņa, A. \& Ruža, A. (2015). Weather conditions effect on fresh and stored winter wheat grain gluten quantity and quality. Nordic View To Sustainable Rural Development. Proceedings of the 25th NJF Congress, 148-153, 16-18 June, Riga, Latvia.

[35] Grausgruber, H., Oberforster, M., Werteber, M., Ruckenbauer, P. \& Volmann, J. (2000). Stability of quality traits in austrian-grown winter wheats. Field Crops Research, 66 (3): 257- 267.

[36] Šramková, Z., Gregová, E. \& Šturdík, E. (2009). Chemical composition and nutritional quality of wheat grain. Acta Chimica Slovaca, 2(1): 115-138.

[37] Koca, Y. O., Dere, Ş. \& Erekul, O. (2011). İleri ekmeklik buğday hatlarında tane verimi ve bazı kalite özelliklerinin belirlenmesi. ADÜ Ziraat Fakültesi Dergisi, 8(2): 15-22.

[38] Brand, T.S., Cruywagen, C.W., Brandt, D.A., Viljoen, M. \& Burger, W.W. (2003). Variation in the chemical composition, physical characteristics and energy values of cereal grains produced in the western cape area of South Africa. South African Journal of Animal Science, 33 (2): 117-126.

[39] Namlı, A., Akça, M. O., \& Akça, H. (2019). Afşin-Elbistan havzası linyit işletmesi organik materyallerinden geliştirilen organik ve organomineral gübrelerin buğday verimi ve verim bileşenleri ile bazı toprak özellikleri üzerine etkileri. Toprak Bilimi ve Bitki Besleme Dergisi, 7(1), 10-20.

[40] GÜNGÖR, H., \& DUMLUPINAR, Z. (2019). Bolu Koşullarında Bazı Ekmeklik Buğday (Triticum aestivum L.) Çeşitlerinin Verim, Verim Unsurları ve Kalite Yönünden Değerlendirilmesi. Türk Tarım ve Doğa Bilimleri Dergisi, 6(1), 44-51.

[41] Boru, K., Yıldırım, S., \& ÇİFCI, E. A. (2019). Ekmeklik Buğday Genotiplerinde Verim ve Verim Öğelerinin Korelasyon ve Path Analizi ile İncelenmesi. Türk Tarım ve Doğa Bilimleri Dergisi, 6(3), 379387. 